\title{
Relationship between cultivation mode of white rot fungi and their efficiency for olive oil mill wastewaters treatment
}

\author{
Sanae Mdaghri Alaoui \\ Laboratoire de Microbiologie de l'Environnement \\ Faculté des Sciences Dhar El Mehraz \\ Université Sidi Mohamed Ben Abdallah \\ B.P: 1796 Atlas-Fès, Morocco \\ E-mail: mdaghrialaouis@yahoo.fr \\ Mohamed Merzouki \\ Laboratoire de Microbiologie de l'Environnement \\ Faculté des Sciences Dhar El Mehraz \\ Université Sidi Mohamed Ben Abdallah \\ B.P: 1796 Atlas-Fès, Morocco \\ E-mail: merzoukimo@yahoo.fr \\ Michel J. Penninckx* \\ Laboratoire de Physiologie et Ecologie Microbienne \\ Faculté des Sciences \\ Université libre de Bruxelles \\ Belgique \\ Tel: 3223733303 \\ Fax: 3223733303 \\ E-mail: upemulb@resulb.ulb.ac.be \\ Mohamed Benlemlih \\ Laboratoire de Microbiologie de l'Environnement \\ Faculté des Sciences Dhar El Mehraz \\ Université Sidi Mohamed Ben Abdallah \\ B.P: 1796 Atlas-Fès, Morocco \\ Tel: 21261900848 \\ Fax: 21255732981 \\ E-mail: benlemlihmo@yahoo.fr
}

Financial support: The authors wish to thank the "Walloon region of Belgium" and the "Association des Universités Francophones" for their financial support.

Keywords: biotreatment, cell immobilization, olive oil mill wastewaters, white rot fungi.

$\begin{array}{ll}\text { Abbreviations: } & \text { COD: chemical oxygen demand } \\ & \text { NT: total nitrogen } \\ & \text { OOMW: olive oil mill wastewaters } \\ & \text { TDM: total dry matter } \\ & \text { TSS: total suspended solids } \\ \text { VM: volatile matter } \\ \text { WRF: white rot fungi }\end{array}$

Four white rot fungi (WRF) strains, Phanerochaete chrysosporium, Trametes versicolor, Coriolopsis polyzona and Pycnoporus coccineus, were tested for efficiency of treatment of Olive Oil mill wastewaters (OOMW) in relation with their cultivation mode, i.e. under the form of free mycelium, mycelium immobilized in alginate beads and solid state cultivation on Petri dishes. Study of biodegradation of phenolic compounds, chemical oxygen demand (COD) decrease and decolourisation of OOMW have shown that Coriolopsis polyzona and Pycnoporus coccineus degradation performances were apparently only slightly affected by the cell cultivation procedures experienced here. In contrast, Phanerochaete chrysosporium and Trametes versicolor showed respectively marked preferences for solid state and alginate immobilisation procedures. Both mono and polyphenolics were reduced to different extent during incubation depending on the strain, as shown by gel filtration analysis. Final pH obtained after fungal treatment of the OOMW based medium (initial pH of 5.0) was measured in order to evaluate the possibility of releasing friendly the treated wastewater in the

*Corresponding author 
environment. Laboratory studies as reported here may be useful for orienting the choice of a strain for treating pollution by OOMW in a particular real situation.

OOMW generates enormous environmental pollution problems all around the Mediterranean basin, in particular in North Africa. The biological cleaning of this effluent is particularly delicate due to a high concentration of phenolic compounds primarily made up of anthocyanidines (McClure, 1979), tannins (Balice et al. 1982) and lignin derivatives (Diaz, 1983).

Basidiomycetes, mainly of the WRF group, were shown to be able to mineralize lignin (Trovaslet et al. 2007) and phenolic compounds (Pointing, 2001) by using a multienzyme system including Lignin peroxidase (LiP: EC. 1.11.1.1) (Martínez, 2002), Manganese peroxidase (MnP: EC. 1.11.1.13) (Hofrichter, 2002) and Laccase (EC. 1.10.3.2) (Castro et al. 2003). A number of fungal strains, among which the WRF strain Phanerochaete chrysosporium, were shown to be active in the treatment of OOMW (Martínez, 2002). To undertake fungal OOMW biotreatment, several procedures were used, such as cultivation on solid and liquid medium, and cultivation under free or immobilized form (Dorado et al. 1999; D' Annibale et al. 2000; Raghukumar et al. 2004; Songulashvili et al. 2007). However, as a consequence of the use of different cultivation procedures by the different authors in the field, data received are often not fully comparable, in particular when considering performances of individual strains. This prompted us to study more systematically the effects of cell cultivation procedures on the physiological behaviour of some strains used in the treatment OOMW.

Performances of four strains of WRF basidiomycetes previously reported to be able to degrade a broad spectrum of phenolic compounds, Phanerochaete chrysosporium, Trametes versicolor, Coriolopsis polyzona and Pycnoporus coccineus (Jaouani et al. 2003) were compared in three cultivation conditions including free mycelium in liquid culture, mycelium immobilized in alginate beads and solid state cultivation on Petri dishes.

\section{MATERIALS AND METHODS}

\section{Olive oil mill wastewater}

OOMW was obtained from a press extraction system located in a factory close to Fez - Morocco (Table 1). The material was collected in plastic containers and stored at $4^{\circ} \mathrm{C}$. Before use, OOMW was diluted with distilled water and sterilized during $15 \mathrm{~min}$ at $121^{\circ} \mathrm{C}$.

\section{Strains}

The four WRF strains used in this study were from the BCCM/ MUCL (Belgium Coordinated Collections of Micro-organisms / Mycothèque of the Catholic University of Louvain). Before inoculation of the tested media, Phanerochaete chrysosporium (MUCL 19343), Trametes versicolor (MUCL 30871), Coriolopsis polyzona (MUCL

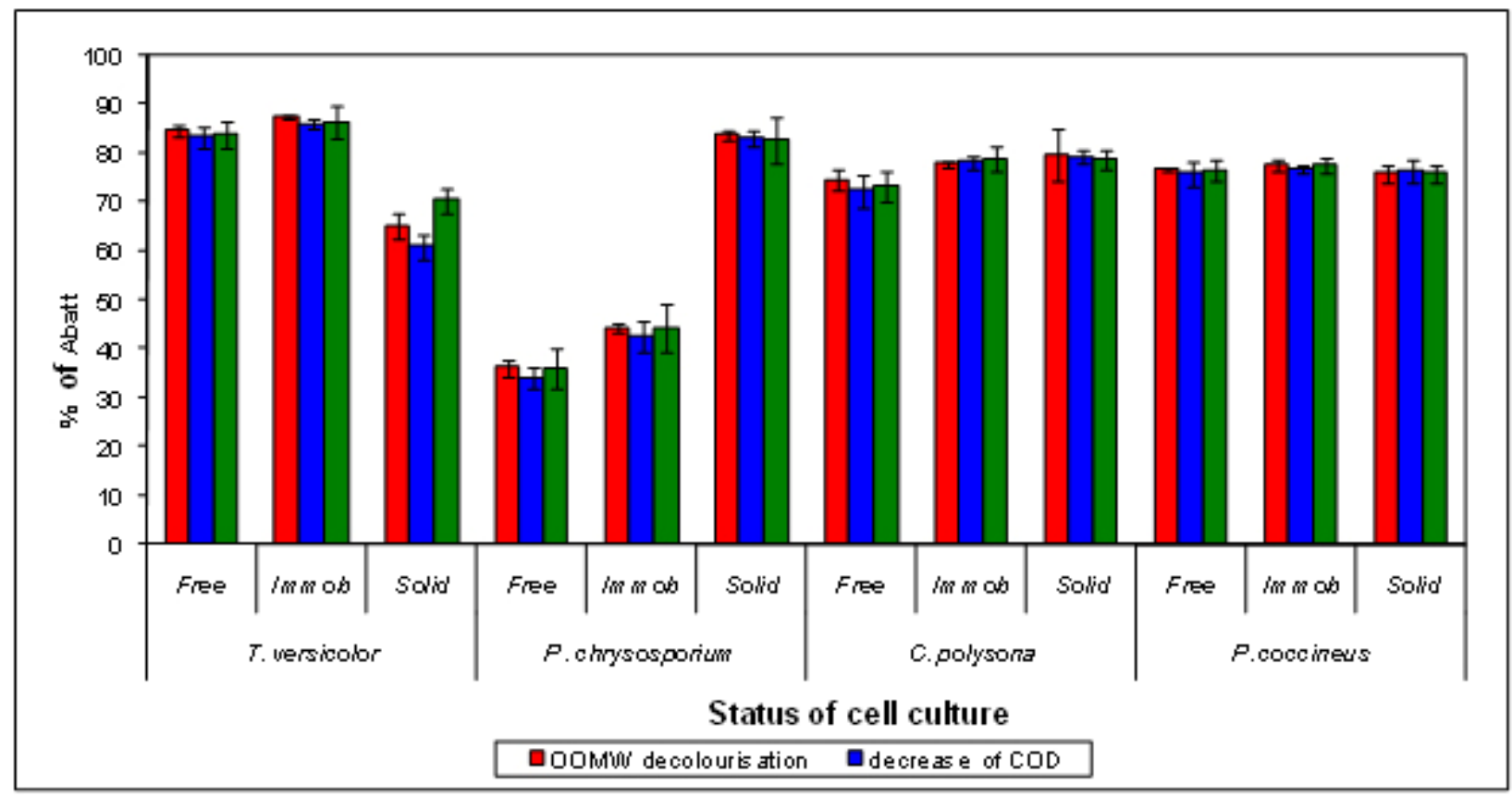

Figure 1. Effect of cell cultivation procedure on OOMW decolourisation, decrease of COD and phenolics. Strains were cultivated during 15 days; Free: cultivation under free form; Immob: immobilized form; Solid: solid state cultivation. All tests were performed in triplicate. Mean values were shown on the graph and error bars were estimated from the 3 values for each result. 
38443) and Pycnoporus coccineus (MUCL 38527) were maintained at $4^{\circ} \mathrm{C}$ on Malt extract solid medium (Difco) 2\% $(\mathrm{w} / \mathrm{v})$.

\section{Pre cultivation and preparation of the inoculum}

Each strain was precultivated three days at $28^{\circ} \mathrm{C}$ in $25 \mathrm{ml}$ of malt extract medium $(20 \mathrm{~g} / \mathrm{l})$ contained in $250 \mathrm{ml}$ Erlenmeyer flasks. The mycelium was recovered by centrifugation during $20 \mathrm{~min}$ at $6,000 \mathrm{~g}$, and further washed with sterile physiological water. Vortex dispersion of the mycelium was carried out discontinuously in a sterile tube during $5 \mathrm{~min}$ in the presence of glass beads (diameter 0.5$0,75 \mathrm{~mm}$, Kolo SA, Belgium). The homogenate was centrifuged at 6,000 $\mathrm{g}$ for $15 \mathrm{~min}$ and washed twice. The recovered pellet was weighed and resuspended in $10 \mathrm{ml}$ of sterile diluted OOMW to be used as inoculums for further experiments. Appropriately diluted inoculums of $\mathrm{OD}_{620 \mathrm{~nm}}=$ 1.6 were used for further experiments.

\section{Cultivation medium}

OOMW diluted fourfold (v/v) with distilled water, and without any complementation was used as a basal cultivation medium. Initial COD and phenolics content of this medium were respectively $26 \pm 0.4$ and $2.6 \pm 0.2 \mathrm{~g} \mathrm{l}^{-1}$. Initial $\mathrm{pH}$ of the medium was $5.0 \pm 0.1$.

\section{Cell immobilization in alginate beads}

Cell immobilization was carried out by restriction of the cells in a calcium alginate matrix. Two $\mathrm{ml}$ of the dispersed mycelium $\left(\mathrm{OD}_{620 \mathrm{~nm}}=1.6\right)$, were mixed with sodium alginate (Sigma) (2\%), and then homogenized in a sterile syringe. The mixture was dropped in a sterile $0.1 \mathrm{M}$ calcium chloride solution to form the beads containing the fungal cells. The formed beads were consolidated at $37^{\circ} \mathrm{C}$ during $15 \mathrm{~min}$. Thereafter the alginate beads were washed with physiological water $(0.9 \% \mathrm{NaCl})$ in order to eliminate calcium chloride traces and free cells. The immobilized cells were added to the cultivation medium. In control experiments, sodium alginate beads were prepared without the addition of living mycelium and were further subjected to the same treatment as immobilized cells.

\section{Cultivation in liquid medium with free and immobilized mycelium.}

Twenty five $\mathrm{ml}$ of the cultivation medium, contained in 250 $\mathrm{ml}$ Erlenmeyer flask, were supplemented with $2 \mathrm{ml}$ of the fungal inoculums $\left(\mathrm{OD}_{620 \mathrm{~nm}}=1.6\right)$ obtained as described above. Incubation was further conducted at $28^{\circ} \mathrm{C}$ as described in Results. A corresponding amount of biomass was used for cultivation with alginate immobilized cells.

\section{Cultivation on solid OOMW based medium}

OOMW diluted fourfold (v/v) with distilled water was supplemented with $15 \mathrm{~g} \mathrm{l}^{-1}$ agar (Difco), and further sterilized for $15 \mathrm{~min}$ at $121^{\circ} \mathrm{C}$. Surface inoculation at the centre of each Petri dish containing this medium was carried out with one plug of agar sampled with a hollowpunch of $4 \mathrm{~mm}$ diameter at the margin of the colony of a seven days malt extract agar culture of the tested strain.

The incubation temperature was maintained at $28^{\circ} \mathrm{C}$ and radial growth measurements were recorded each day during 15 days. Decrease of COD, colour and phenolic compounds were measured at the end of growth after extraction of the agar bead with distilled water.

\section{Analytical procedures}

Phenolic compounds soluble in OMWW were determined using the colorimetric procedure described in Aissam et al. (2005). Results was expressed as g of tannic acid.$^{-1}$.

Chemical oxygen demand (COD) evolution expressed in $g$ of $\mathrm{O}_{2} . \mathrm{l}^{-1}$ was estimated according to Aissam et al. (2005).

Decolourization of OOMW was evaluated by measurement of absorbance decrease at $395 \mathrm{~nm}$.

Total suspended solids (TSS) in OOMW were determined by centrifugation of a $20 \mathrm{ml}$ sample of the waste at $8,000 \mathrm{x}$ $\mathrm{g}$ for $20 \mathrm{~min}$. The centrifugation pellet was transferred quantitatively in a cup of porcelain before weighing and then dried at $105^{\circ} \mathrm{C}$ during $24 \mathrm{hrs}$. TSS was expressed in g. $1^{-1}$.

Total dry matter (TDM) was determined after evaporation of a $10 \mathrm{ml} \mathrm{OOMW}$ sample in a porcelain cup at $105^{\circ} \mathrm{C}$ for $24 \mathrm{hrs}$. TDM was expressed in g. $\mathrm{l}^{-1}$. Volatile Matter (VM) was determined by the difference between the total dry matter obtained by evaporation at $105^{\circ} \mathrm{C}$ and the residue resulting from ignition at $600^{\circ} \mathrm{C}$ for 2 hrs. VM was expressed in $\mathrm{gl}^{-1}$ as compared to dry weight. Chloride content (g. $\mathrm{l}^{-1}$ ) of OOMW was determined by the volumetric procedure of Mohr (Rodier, 1996). Total nitrogen (NT) (g.l ${ }^{-1}$ ) was determined by the Kjeldahl procedure (Rodier, 1996). Orthophosphates $\left(\mathrm{PO}_{4}^{3-}\right)\left(\mathrm{g}^{3} \mathrm{l}^{-1}\right)$ were determined by the method of Murphy and Riley (1962). $\mathrm{Na}^{+}$ions (g. ${ }^{-1}$ ) were measured with a flame spectrophotometer (type PHF $90 \mathrm{D}$; ISA Biology) in samples of OOMW filtered and appropriately diluted with distilled water. Total sugars were measured by the method of Dubois et al. (1956). For estimating total lipids, seventy five $\mathrm{ml}$ of chloroform and $100 \mathrm{ml}$ of methanol were added to $100 \mathrm{ml}$ of OOMW. After shaking and further settling, the mixture was divided into two phases. The upper methanol phase was eliminated, while the lower phase containing chloroform and soluble lipids was evaporated in a Rotavapor device. The amount of lipids recovered was expressed in g. $1^{-1}$ OOMW. All the colorimetric determinations were carried out with a UVvisible spectrophotometer (Brand Jenway 6105).

\section{Size exclusion chromatography}

Molecular weight pattern of phenolics compounds in OOMW before and after 15 days fungal treatment was 

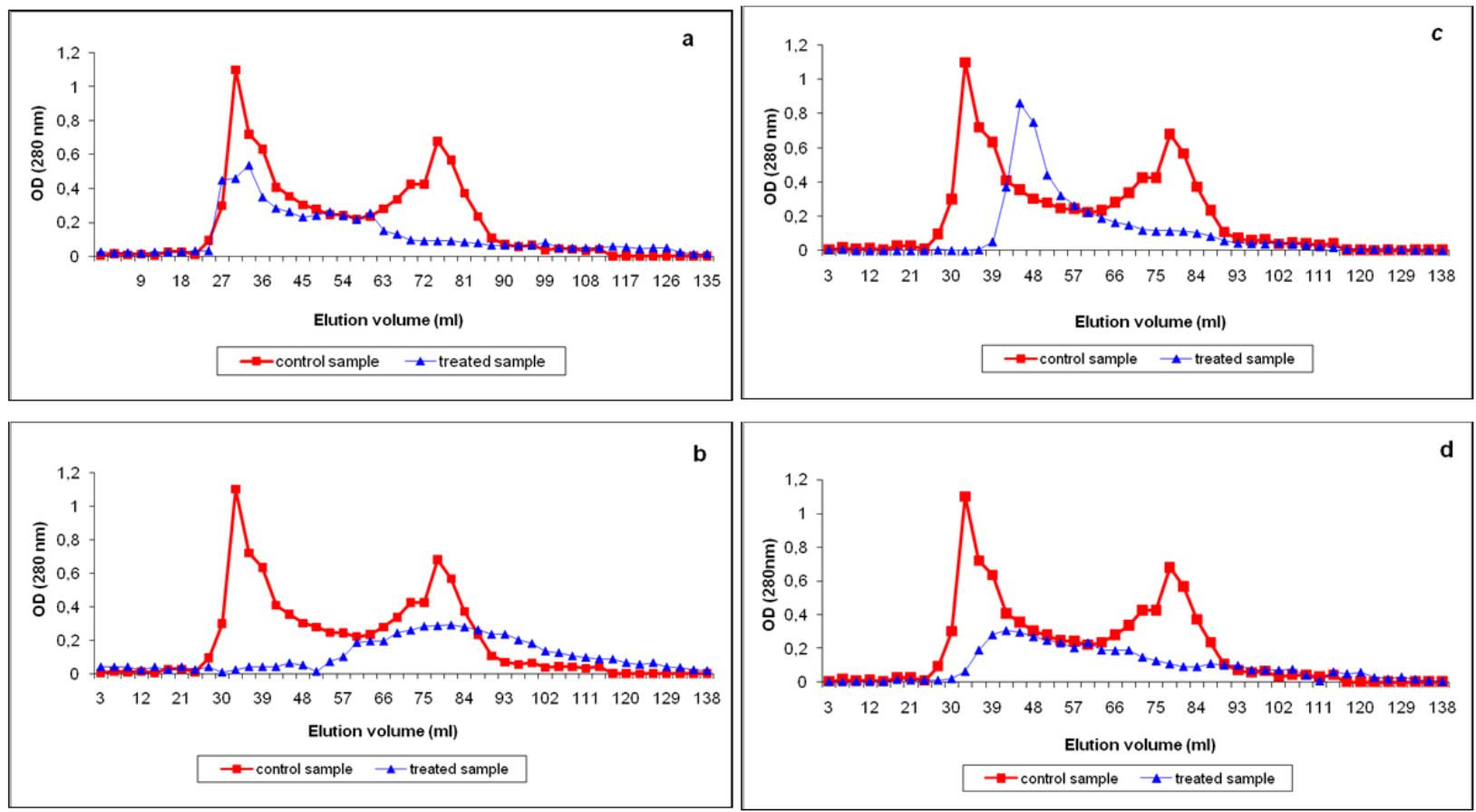

Figure 2. Sephadex G 50 elution pattern of phenolic compounds present in OOMW after treatment with:

(a) immobilized $T$. versicolor.

(b) free mycelium of $P$. coccineus.

(c) solid state cultivated $P$. chrysosporium.

(d) solid state cultivated C. polyzona.

determined by size exclusion chromatography on a Sephadex G 50 column (2.5 cm diameter X $75 \mathrm{~cm}$ height) as described by Jaouani et al. (2005). The phenolic fractions were detected at $280 \mathrm{~nm}$. Sterile incubated control was obtained by incubating heat killed biomass $\left(121^{\circ} \mathrm{C}, 15\right.$ min) in the presence of the OOMW.

\section{RESULTS}

\section{Effect of cultivation conditions on general parameters of OOMW fungal biotreatment}

The main objective of this investigation was to delimit conditions for high and prolonged activity of WRF for treatment of OOMW, especially to decolourize the waste and eliminate phenolic compounds and other COD contributing substances (sugars, lipids). In order to clarify the metabolic trends of the studied strains, we have studied for each strain, as stated above, the effects of different cell cultivation modes on OOMW decolourisation, decrease of COD and phenolics. Figure 1 synthesizes the data obtained with the different strains cultivated under three modes. Among the four studied strains, P. chrysosporium was apparently the strain mainly affected by the cultivation mode. If $P$. chrysosporium was comparable to the other strains in terms of COD, phenolics decrease and decolourisation, when cultivated under solid state form, this strain exhibited comparatively modest performances under free and alginate immobilized forms Reduction of the different studied parameters by $T$. versicolor, C. polyzona and $P$. coccineus were very comparable, accounting for in most of the cases $85 \%$ and more reduction. Yet, lowest significant values (around $65-70 \%$ decrease) were observed for $T$. versicolor cultivated under solid state form.

\section{Effect of OOMW biotreatment on final $\mathrm{pH}$ of the effluent}

Effect of OOMW biotreatment on final $\mathrm{pH}$ of the effluent was an interesting parameter to monitor because reduction of acidity of treated OOMW should be a desirable goal to attain before release of the waste in the environment. The $\mathrm{pH}$ evolution data (not illustrated) showed that except for C. polyzona the strains presented similar behaviour. The $\mathrm{pH}$ increased after treatment under solid culture condition and decreased under liquid culture conditions (free and mainly immobilized). On solid medium the $\mathrm{pH}$ increased in a very significant way. Initial pH before treatment was $5.0 \pm 0.1$. Final value obtained with the free form of $C$. polyzona was $5.5 \pm 0.1$, whereas was apparently only slightly affected by other types of cultivation for this particular strain. A significant $\mathrm{pH}$ decrease of 0.5 units was observed for $T$. 
Table1. Composition of crude OOMW used in the present investigation. Analytical procedures used to determine the composition of crude OOMW are described in Material and Methods. All tests were performed in triplicate. The data reported corresponded to mean values with a standard error less than $7 \%$.

\begin{tabular}{|l|l|}
\hline $\mathrm{pH}$ & 5.00 \\
\hline Matter in suspension $\left(\mathrm{g} . \mathrm{I}^{-1}\right)$ & 32.00 \\
\hline Dry Matter $\left(\mathrm{g} \cdot \mathrm{I}^{-1}\right)$ & 100.00 \\
\hline Volatile matter $\left(\mathrm{g} . \mathrm{I}^{-1}\right)$ & 21.00 \\
\hline Lipids $\left(\mathrm{g} . \mathrm{I}^{-1}\right)$ & 1.00 \\
\hline Chemical Oxygen demand (COD) $\left(\mathrm{g}\right.$ of $\left.\mathrm{O}_{2} \cdot \mathrm{I}^{-1}\right)$ & 106.00 \\
\hline Phenolic compounds $\left(\mathrm{g} . \mathrm{I}^{-1}\right)$ & 12.90 \\
\hline Total sugars $\left(\mathrm{g} . \mathrm{I}^{-1}\right)$ & 0,41 \\
\hline Sodium $\left(\mathrm{g} . \mathrm{I}^{-1}\right)$ & 2.10 \\
\hline Chlorides $\left(\mathrm{g} . \mathrm{I}^{-1}\right)$ & 3.20 \\
\hline Orthophosphates $\left(\mathrm{g} . \mathrm{I}^{-1}\right)$ & 0,09 \\
\hline Total Nitrogen $\left(\mathrm{g} . \mathrm{I}^{-1}\right)$ & 0,17 \\
\hline
\end{tabular}

versicolor, $P$. chrysosporium and $P$. coccineus under immobilized form. The more important $\mathrm{pH}$ drops were observed for $P$. coccineus and $P$. chrysosporium growing under free form, respectively attaining 4.25 and 4.5 values.

\section{Effect of fungal treatment on molecular weight distribution of phenolic compounds}

The purpose of this investigation was to evaluate the differential effects of the four studied strains and their cultivation conditions on the low and high molecular weights fractions of phenolics present in OOMW. The twelve situations described in Figure 1 were examined. Four typical situations, summarising the situations encountered during this investigation were illustrated here. Before treatment, a typical elution chromatogram of the OOMW based medium showed two main peaks representing respectively phenolic compounds of more than $30 \mathrm{kDa}$ and $2 \mathrm{kDa}$ molecular masses (Figure 2a; Figure 2d).The same pattern was obtained when using killed controls (not illustrated); For all the twelve treatments studied, the lower molecular masses phenolics practically disappeared, except for $P$. chrysosporium under solid state where attenuation was only partial (Figure 2c). The amplitude of high molecular masses elution peaks was also systematically lower for all cases studied and complete for $P$. chrysosporium (Figure 2c). For P. coccineus growing under free form (Figure 2b), and $C$. polyzona growing in solid state condition (Figure 2d), we observed an apparent shift towards intermediate molecular masses.

\section{Studies of laccase production}

Laccase was previously identified as a main enzyme involved in the degradation of phenolics in OOMW (Jaouani et al. 2005). The highest laccase content in cultivation supernatant was for C. polyzona under free and immobilized forms. In contrast, only low laccase production was generally observed after 15 days incubation.

\section{DISCUSSION}

The degradation capacities of fungi, in particular white rot strains, were studied for more than twenty years (Field et al. 1993; Pelaez et al. 1995). A lot of data were obtained concerning treatment of pulp and paper, (Kondo et al. 1994; Taspinar and Kolankaya, 1998; De Souza-Cruz et al. 2004; Gamelas et al. 2005), dyes and textile (Lucas et al. 2008), oxidation of polycyclic aromatic hydrocarbons (Zheng and Obbard, 2002) and OOMW (Sayadi and Ellouz, 1995; Jaouani et al. 2005). Yet, the research domain often suffered from difficulty of comparison between the published information, mainly because of the use of different cultivation procedures by different authors, and even in several cases poor description of cultivation mode. The present contribution focused on four WRF strains reputed for their capacity of degrading recalcitrant macromolecules, present in different wastes (Baldrian et al. 2000; Ford et al. 2007). From our results, two major groups apparently emerged, respectively slightly (or not) or 


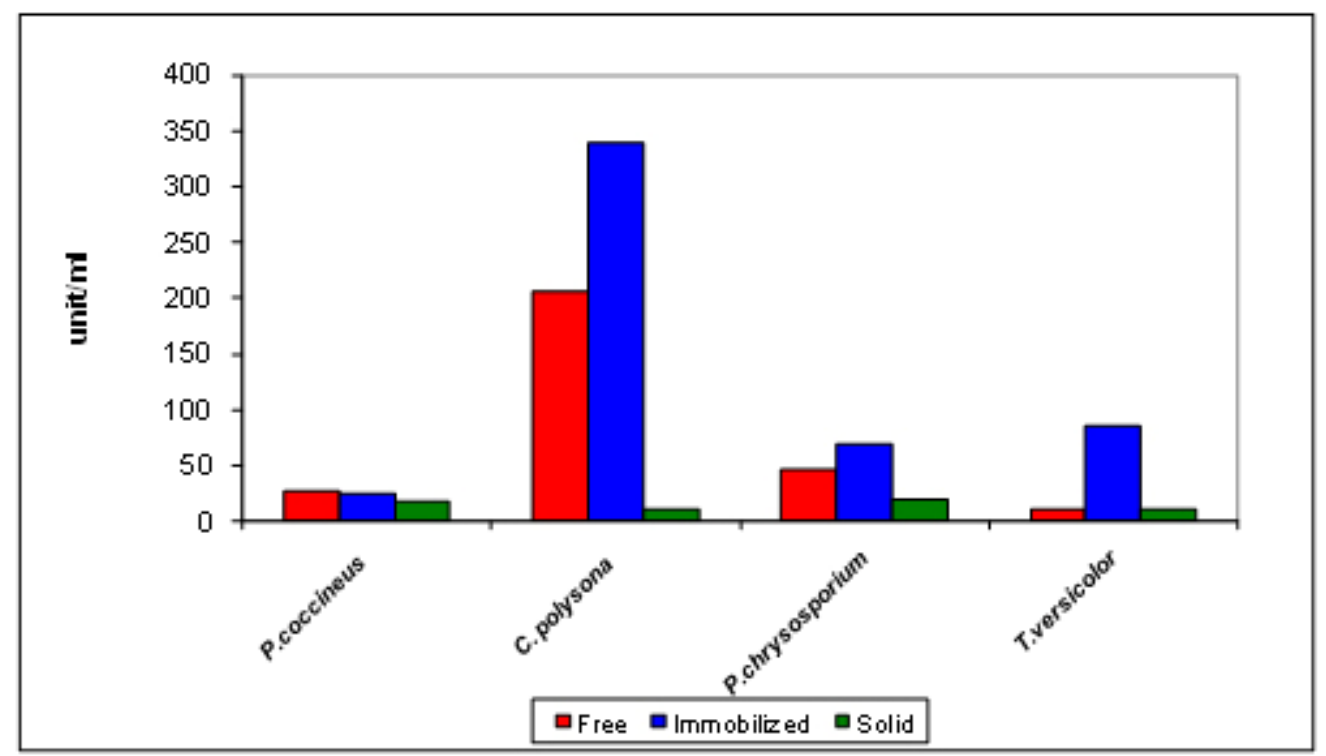

Figure 3. Laccase production by the strains under various culture conditions. The enzyme level was measured in cultivation supernatant after 15 days of cultivation.

strongly affected by the cultivation mode. Data were obtained after 15 days of incubation, corresponding to a period of treatment often used by several authors, and corresponding to maximal decrease of COD and phenolics (Kissi et al. 2001; Jaouani et al. 2003). The first group included $C$. polyzona and $P$. coccineus. Therefore, strains of this first group could be selected for bioremediation in context permitting only restricted cultivation modes. An example is the in situ cleaning of an OOMW contaminated soil, where bioaugmentation with an active strain is a possible technique. This particular strategy is obviously related to solid state cultivation. When treating a liquid effluent, a procedure using immobilized cells of $C$. polyzona and $P$. coccineus should be appropriate. The use of fungi belonging to the second group, including here $P$. chrysosporium and $T$. versicolor, should be more restricted to particular cases. For example, if $P$. chrysosporium could be used for solid state procedures, the strain has only limited use for liquid effluents as compared to WRF of the first group. An interesting feature shared by all the studied fungi is their capacity to decolourize and degrade phenolics without any supplementation of the OOMW based medium. This was previously reported for certain strains; in particular P. chrysosporium (Kissi et al. 2001; Sayadi and Ellouz, 1995). This could however result from the origin of the strain and/or the OOMW. In fact, qualitative and quantitative differences in carbon, nitrogen, phosphorus composition and nature of phenolic compounds contents between different OOMW have been reported (El Hadrami et al. 2004).

Gel filtration experiments have shown that both high and low Molecular Masses phenolics are degraded and assimilated by the WRF. This corroborates previous observations (Sayadi and Ellouz, 1995) for $P$. chrysosporium and for C. polyzona (Jaouani et al. 2005). In the case of $P$. coccineus, growing in the form of free mycelium, and C. polyzona in solid state form, we have observed new peaks corresponding to intermediate molecular masses, possibly originating from partial depolymerisation of the heavy polyphenols fraction and/or laccase mediated partial repolymerisation of low molecular mass phenolics (Jaouani et al. 2005). However, a study of laccase production by the strains (Figure 3) did not reveal clear correlation between laccase production and degradation/ repolymerisation capacities. Yet, it should be mentioned that laccase levels were determined here after 15 days cultivation. Intermediate values would be useful to determine in order to establish if any correlation exists between laccase activity and phenolics degradation. It was for example shown that ligninolytic enzymes may be sensitive to proteases produced by different WRF strains during their growth cycle (Jimenez-Tobon et al. 2003). Although, apparently not detected in the present investigation (not illustrated), the role of other enzymes, including Lignin peroxidase, Manganese peroxidase (Kondo et al. 1994; Belinky et al. 2003; Songulashvili et al. 2007) and cellobiose dehydrogenase (Vanhulle et al. 2007) should be also evaluated in more details. For example, Sayadi and Ellouz (1995) reported a possible role for Lignin Peroxydase and Manganese Peroxydase from Phanerochaete chrysosporium in the decolourization of OOMW. Aissam et al. (2005) have detected a Manganese peroxidase activity produced by a Aspergillus niger strain degrading polyphenols in OOMW.

Another important point related to a successful biotreatment is to attain an environmentally friendly final 
wastewater, in particular characterized by a reduction of acidity. This should be also taken more carefully into account. As shown here, this was achieved at least partially with $C$. polyzona and $T$. versicolor under certain cultivation conditions but not with most of the immobilized forms of other strains. As another example, El Asli et al. (2005) have shown that immobilization of a bacterial strain may in fact result in acidification of a growing medium containing OOMW.

In conclusion, we think that laboratory studies as reported here may be useful for orienting the choice of a strain for treating pollution by OOMW. Improvement of experiments in microcosms reproducing at best the different situations that could be encountered in real situations should be a desirable future research axis. A search for the hidden reasons explaining the different behaviours of strains should be also investigated in order to provide a rationale in the use of WRF for bioremediation of pollution generated by OOMW. In this particular context we think that it would be fruitful to assess the individual sensitivities of the strains to constraints imposed by the different forms of growth to diffusion of oxygen and nutrients towards the cells.

\section{REFERENCES}

AISSAM, H.; ERRACHIDI, F.; PENNINCKX, M.J.; MERZOUKI, M. and BENLEMLIH, M. Production of Tannase by Aspergillus niger HA37 growing on tannic acid and Olive Mill Waste Water. World Journal of Microbiology and Biotechnology, June 2005, vol. 21, no. 4, p. 609-614.

BALDRIAN, P.; DER WIESCHE, C.; GABRIEL, J.; NERUD, F. and ZADRAZIL, F. Influence of cadmium and mercury on activities of ligninolytic enzymes and degradation of polycyclic aromatic hydrocarbons by Pleurotus ostreatus in soil. Applied and Environmental Microbiology, June 2000, vol. 66, no. 6, p. 2471-2478.

BALICE, V.; BOARI, G.; CERA, O. and ABBATICCHIO, $P$. Indagine analitica sulle acque di vegetazione. Inquinamento, 1982, vol. 7, p. 49-53.

BELINKY, P.A.; FLINSHTEIN, N.; LECHENKO, S.; GEPSTEIN, S. and DOSORETZ, C. Reactive oxygen species and induction of lignin peroxydase in Phanerocheate chrysosporium. Applied and Environmental Microbiology, November 2003, vol. 69, no. 11, p. 65006506.

CASTRO, A.I.R.P.; EVTUGUIN, D.V. and XAVIER, A.M.R.B. Degradation of biphenyl lignin model compounds by laccase of Trametes versicolor in the presence of 1-hydroxybenzotriazole and heteropolyanion [SiW11VO40]5-. Journal of Molecular Catalysis B: Enzymatic, April 2003, vol. 22, no. 1-2, p. 13-20.

D'ANNIBALE, A.; STAZI, S. R.; VINCIGUERRA, G. and SERMANI, G. Oxirane-immobilized Lentinula edodes
Laccase: Stability and phenolics removal efficiency in olive mill wastewater. Journal of Biotechnology, February 2000, vol. 77, no. 2-3, p. 265-273.

DE SOUZA-CRUZ, P.B.; FREER, J.; AHO, M.S. and MARCH, A.F. Extraction and determination of enzymes produced by Ceriporiopsis subvermispora during biopulping of Pinus taeda wood chips. Enzyme and Microbial Technology, March 2004, vol. 34, no. 3-4, p. 228-234.

DIAZ, F. Olives. In: REHM H.J. and REED G. eds. Biotechnology. Verlag Chemie Weinheim, Federal Republic of Germany, 1983, vol. 5, p. 379-397.

DORADO, J.; ALMENDROS, G.; CAMARERO, S.; MARTÍNEZ, A.T.; VARES, T. and HATAKKA, A. Transformation of wheat straw in the course of solid-state fermentation by four ligninolytic basidiomycetes, Enzyme and Microbial Technology, October 1999, vol. 25, no. 7, p. 605-612.

DUBOIS, M; GILLES, D.A.; HAMILTON, J.K.; REBERS, P.A. and SMITH, F. Colorimetric method for the determination of sugars and related substances. Analytical Chemistry, March 1956, vol. 28, no. 3, p. 350-356.

El ASLI, A.; ERRACHIDI, F.; BENNISSE, G.; QATIBI, A. and ERRAMI, M. Effect of cell immobilization on the treatment of olive mill wastewater by a total phenols, acetic acid and formic acid degrading bacterium strain. Grasas y Aceites, April 2005, vol. 56, no. 2, p. 116-120.

EL HADRAMI, A.; BELAQZIZ, M.; EL HASSNI, M.; HANIFI, S.; ABBAD, A.; CAPASSO, R; GIANFREDA, L. and EL HADRAMI, I. Physico-chemical characterization and effects of olive oil mill wastewaters fertirrigation on the growth of some mediterranean crops. Journal of Agronomy, October 2004, vol. 3, no. 4, p. 247-254.

FIELD, J.A.; DE JONG, E.; FEIJOO-COSTA, G. and DE BONT, J.A.M. Screening for ligninolytic fungi applicable to the biodegradation of xenobiotics. Trends in Biotechnology, February 1993, vol. 11, no. 2, p. 44-49.

FORD, C.I.; WALTER, M.; NORTHCOTT, G.L.; DI, H.J.; CAMERON, K.C. and TROWER, T. Fungal inoculum properties: extracellular enzyme expression and pentachlorophenol removal by New Zealand Trametes species in contaminated field soils. Journal of Environmental Quality, October 2007, vol. 36, no. 6, p. 1749-1759.

GAMELAS, J.A.F.; TAVARES, A.P.M.; EVTUGUIN D.V. and XAVIER, A.M.B. Oxygen bleaching of kraft pulp with polyoxometalates and laccase applying a novel multistage process. Journal of Molecular Catalysis B: Enzymatic, June 2005, vol. 33, no. 3-6, p. 57-64. 
HOFRICHTER, M. Review: lignin conversion by manganese peroxidase (MnP). Enzyme and Microbial Technology, April 2002, vol. 30, no. 4, p. 454-466.

JAOUANI, A.; SAYADI, S.; VANTHOURNHOUT, M. and PENNINCKX, M.J. Potent fungi for decolourisation of olive oil mill wastewaters. Enzyme and Microbial Technology, November 2003, vol. 33, no. 6, p. 802-809.

JAOUANI, A.; GUILLEN, F.; PENNINCKX, M.J.; MARTINEZ, A.T. and MARTINEZ, M.J. Role of Pycnoporus coccineus laccase in the degradation of aromatic compounds in olive oil mill wastewater. Enzyme and Microbial Technology, March 2005, vol. 36, no. 4, p. 478-486.

JIMENEZ-TOBON, G.; KURZATKOWSKI, W.; ROZBICKA, B.; SOLECKA, J.; PÓCSI, I. and PENNINCKX, M.J. In situ localization of manganese peroxidase production in mycelial pellets of Phanerochaete chrysosporium. Microbiology, November 2003, vol. 149, p. 3121-3127.

KISSI, M.; MOUNTADAR, M.; ASSOBHEI, O.; GARGIULO, E.; PALMIERI, G.; GIARDINA, P. and SANNIA, G. Roles of two white-rot basidiomycete fungi in decolorisation and detoxification of olive mill waste water. Applied Microbiology and Biotechnology, October 2001, vol. 57, no. 1-2, p. 221-226.

KONDO, R.; HARAZONO, K. and SAKAI, K. Bleaching of hardwood kraft pulp with manganese peroxidase secreted from Phanerochaete sordida YK-642. Applied and Environmental Microbiology, December 1994, vol. 60, no. 12, p. 4359-4363.

LUCAS, M.; MERTENS, V.A.; CORBISIER, M. and VANHULLE, S. Synthetic dyes decolourisation by whiterot fungi: Development of original microtitre plate method and screening. Enzyme and Microbial Technology, January 2008, vol. 42, no. 2, p. 97-106.

MARTÍNEZ, A.T. Review: Molecular biology and structure-function of lignin-degrading heme peroxidases. Enzyme and Microbial Technology, April 2002, vol. 30, no. 4, p. 425-444.

MCCLURE, J.W. Phenolics in the environment. In: Swain T.; Harborne J.B and. Van Sumere, C.F. eds. Biochemistry of Plant Phenolics. Plenum Press, New York, 1979, p. 525545.

MURPHY, J. and RILEY, J.P. A modified simple solution method for the determination of phosphate in natural waters. Analytica Chimica Acta, January 1962, vol. 27, no. 1, p. 31-36.

PELAEZ, F.; MARTINEZ, M.J. and MARTINEZ, A.T. Screening of 68 species of basidiomycetes for enzymes involved in lignin degradation. Mycological Research, January 1995, vol. 99, no. 1, p. 37-42.

POINTING, S.B. Feasibility of bioremediation by Whiterot Fungi. Mini-Review. Applied Microbiology and Biotechnology, June 2001, vol. 57, no. 7, p. 20-33.

RAGHUKUMAR, C.; MOHANDASS, C.; KAMAT, S. and SHAILAJA. M.S. Simultaneous detoxification and decolorization of molasses spent wash by the immobilized white-rot fungus Flavodon flavus isolated from a marine habitat. Enzyme and Microbial Technology, August 2004, vol. 35, no. 2-3, p. 197-202.

RODIER, J. L'analyse de l'eau, $8^{\text {th }}$ ed. Paris, Dunod, 1996, 1434 p. ISBN 9782100496365.

SAYADI, S. and ELLOUZ, R. Roles of lignin peroxydase and manganese peroxydase from Phanearochaete chrysosporium in the decoloration of olive mill wastewater. Applied and Environmental Microbiology, March 1995, vol. 61, no. 3, p. 1098-1103.

SONGULASHVILI, G.; ELISASHVILI, V.; WASSER, S.P.; NEVO, E. and HADAR, Y. Basidiomycetes laccase and manganese peroxidase activity in submerged fermentation of food industry wastes. Enzyme and Microbial Technology, July 2007, vol. 41, no. 1-2, p. 57-61.

TASPINAR, A. and KOLANKAYA, N. Optimization of enzymatic chlorin removal from Kraft pulp. Bulletin of Environmental Contamination, July 1998, vol. 61, no. 1, p. 15-21.

TROVASLET, M.; ENAUD, E.; GUIAVARC'H, Y.; CORBISIER, A.M. and VANHULLE, S. Potential of a Pycnoporus sanguineus laccase in bioremediation of wastewater and kinetic activation in the presence of an anthraquinonic acid dye. Enzyme and Microbial Technology, August 2007, vol. 41, no. 3, p. 368-376.

VANHULLE, S.; ENAUD, E.; TROSVALET, M.; NOUAIMEH, N.; BOLS, C.M. and KESHAVARZ, T. Overlap of laccase/cellobiose dehydrogenase activities during the decolourisation of anthraquinonic dyes with close chemical structure by Pycnoporus strains. Enzyme and Microbial Technology, June 2007, vol. 40, no. 7, p. 1723-1731.

ZHENG, Z. and OBBARD, J.P. Oxidation of polycyclic aromatic hydrocarbons (PAH) by the white rot fungus Phanerochaete chrysosporium. Enzyme and Microbial Technology, July 2002, vol. 31, no. 1-2, p. 3-9. 